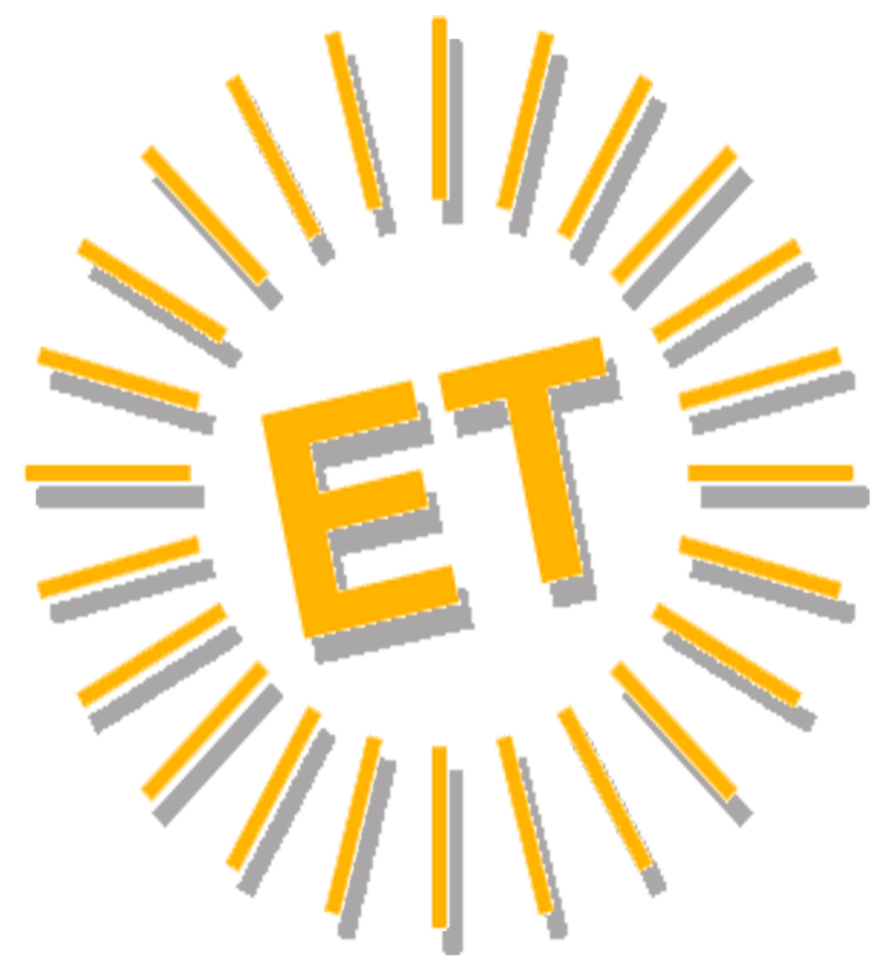




\section{Editorial Team}

\section{Editor in Chief}

Alfonso Vargas-Sánchez, University of Huelva, Spain

\section{Associate Editor}

Mirko Perano, Reald University College, Albania

\section{Books Review Editor}

Brendan Paddison, York St. John University, United Kingdom

\section{Secretariat}

Elena García de Soto, University of Huelva, Spain

Cinta Borrero-Domínguez, University of Seville, Spain

\section{Style reviewer and text editor}

Anestis Fotiadis, Zayed University, United Arab Emirates

\section{Editorial Board}

José Manuel Alcaraz, Murdoch University, Australia Mario Castellanos-Verdugo, University of Seville, Spain José Antonio Fraiz-Brea, University of Vigo, Spain José Manuel Hernández-Mogollón, University of Extremadura, Spain

Tzung-Chen Huan, National Chiayi University, Taiwan, Province of China

Shaul Krakover, Ben Gurion University, Israel Jean Pierre Levy-Mangin, University of Quebec, Canada Tomás López-Guzmán, University of Córdoba, Spain Yasuo Ohe, Chiba University, Japón

María de los Ángeles Plaza-Mejía, University of Huelva, Spain Nuria Porras-Bueno, University of Huelva, Spain João Albino Silva, Algarve University, Portugal

\section{Advisory Board (Spanish Members)}

Juan Manuel Berbel-Pineda, Pablo de Olavide University, Spain César Camisón-Zornoza, Uniersity of Valencia, Spain Enrique Claver-Cortés, University of Alicante, Spain María Teresa Fernández-Alles, University of Cádiz, Spain José Luis Galán-González, University of Seville, Spain Félix Grande-Torraleja, University of Jaén, Spain

Antonio Leal-Millán, University of Seville, Spain Inmaculada Martín-Rojo, University of Málaga, Spain Antonio Manuel Martínez-López, University of Huelva, Spain Francisco José Martínez-López, University of Huelva, Spain Pablo A. Muñoz-Gallego, University of Salamanca, Spain
Francisco Riquel-Ligero, University of Huelva, Spain José Miguel Rodríguez-Antón, Autonomous University of Madrid, Spain

Sandra Sanchez-Cañizares, University of Cordoba, Spain Josep Francesc Valls-Giménez, ESADE, Spain

\section{Advisory Board (Other European Members)}

Tindara Abbate, University of Messina, Italy Paulo Aguas, University of Algarve, Portugal Carlos Costa, Aveiro University, Portugal Dianne Dredge, Aalborg University, Denmark Salvatore Esposito de Falco, University of Rome "La Sapienza", Italy

Sheila Flanagan, Dublín Institute of Technology, Ireland Tania Gorcheva, Tsenov Academy of Economics, Bulgaria Tadeja Jere Jakulin, University of Primorska, Slovenia Metin Kozak, Mugla University, Turkey Álvaro Matias, Lusiada University, Portugal Alfonso Morvillo, National Research Council, Italy Alexandru Nedelea, Stefan cel Mare University of Suceava, Romania Claudio Nigro, University of Foggia, Italy Angelo Presenza, University "G. D'Annunzio" of Chieti-Pescara, Italy

Kanes Rajah, Royal Agricultural University, United Kingdom

\section{Advisory Board (Members from the rest of the world)}

John Allee, American University of Sharjah, United Arab Emirates

Nestor Pedro Braidot, National University of La Plata, Argentina

Roberto Elias Canese, Columbia University, Rector, Paraguay

Luca Casali, Queensland University of Technology, Australia Nimit Chowdhary, Indian Institute of Tourism and Travel Management, India

Steven Chung-chi Wu, National Pingtung University of Science and Technology, Taiwán

Dianne Dredge, Southern Cross University, Australia Daniel Fesenmaier, Temple University, United States

Babu George, Alaska Pacific University, United States Dogan Gursoy, Washington State University, United States Jafar Jafari, University of Wisconsin-Stout, United States Sanggun Lee, Pai Chai University, Korea Republic of Albert Yeh Shangpao, I-SHOU University, Taiwán Pauline Sheldon, University of Hawaii, United States Germán A. Sierra-Anaya, University of Cartagena de Indias, Rector, Colombia Xiaohua Yang, University of San Francisco, United States 


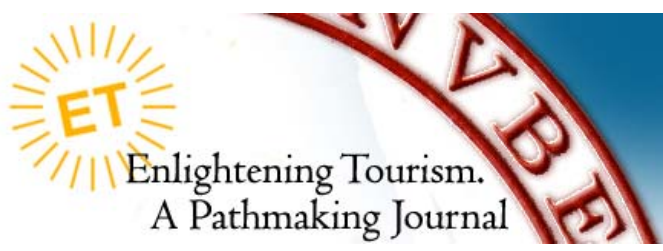

\title{
WILDLIFE TOURISM: A SYNTHESIS OF PAST, PRESENT, AND FUTURE RESEARCH AGENDA
}

\author{
Kota Neela Mani Kanta \\ Vikrama Simhapuri University (India) \\ kotamani2003@yahoo.co.in \\ Rahul Pratap Singh Kaurav \\ Fortune Institute of International Business (India) \\ rsinghkaurav@gmail.com \\ Uday Sankar Allam \\ Vikrama Simhapuri University (India) \\ vsuusareddy@gmail.com \\ P. Srivalli \\ Akshara Vidyalaya (India) \\ kotasrivalli87@gmail.com
}

\begin{abstract}
Wildlife tourism (WT) is an emerging sector of tourism, majorly meant to view and/or encounter wildlife in the wild, captive, and semi-captive settings. Because of the new emerging economies, there is an increased demand for wildlife destinations in both, developing and developed nations. However, a comprehensive study is lacking in WT. In this context, the present study seeks to bring together and discuss the key findings on WT from the present literature and propose new approaches to research using co-citation, co-authorship, and co-occurrence analyses. Further, the study also considers research on WT conducted so far like attitudes, birdwatching, conservation, economics, hunting, mammals, management, marine monitoring, negative impacts, positive impacts, captive wildlife, and 390
\end{abstract}


guidelines. A data set is created that includes authors, article titles, citations, countries, co-authorship, institutions, publication years and sources, keywords, and abstracts by collecting the bibliographies from Scopus and Web of Science (WoS) indexed journals with keywords search "Wild Life, Jungle and Tourism." The study collected 1,519 and used 1,259 published articles from 1990 to 2020, and analyzed employing VOS viewer software, which has enabled us to understand the relationship and structure of the literature.

KEYWORDS

Wildlife Tourism; Flora-Fauna; Conservation Areas; Bibliometric Analysis; VOS Viewer

ECONLIT KEYS

L83; Z31; Z32; Z33

\section{INTRODUCTION}

Wildlife tourism is the world's extensive nature-based tourism activity and is also viewed as a sustainable development tool because it is often described as nonconsumptive and environmentally positive for wildlife (Newsome et al., 2012; Rodger et al., 2007; WTTC, 2019). WT research's epistemology is a topic of ongoing debate and discussion (Benckendorff \& Zehrer, 2013). According to the World Travel and Tourism Council (WTTC), the contribution of WT to the global Gross Domestic Product (GDP) was about the US $\$ 120.1$ billion to or $4.4 \%$ of the estimated direct global travel and tourism GDP of the US $\$ 2,751$ billion in 2018 (WTTC, 2019). The shares of different WT sectors range from 36.3\% in Africa, 8.6\% in Latin America, 5.8\% in Asia-Pacific, and 2\% in North America to just $1.6 \%$ in Europe. Since the last two decades, WT has grown globally and gained more attention from research scholars (Semeniuk et al., 2010; Sedarati, et. al., 2019).

The literature on WT is substantial with diverse areas having been touched upon for research globally. The diverse nature of literature includes areas like conservation, WT, protected areas, attitudes, and behavioral studies of visitors, sustainable development, eco-tourism, and other forms. Dou \& Day (2020), support the findings of this study by stating that the major countries contributing to wildlife and related tourism research include the United States of America (US), Australia, South Africa, and China. The research literature collected ranges from 1990 to 2020 and has been conducted by a wide 
range of universities, government agencies, and conservation and protected areas management agencies. The research contributes to the literature on WT and also to comprehensive efforts of specialists in tourism, geography, environmental science, conservation science, wildlife biology, planning studies, leisure studies, outdoor recreation studies, and recreation ecology.

Xiao \& Smith (2006) and Zhang \& Chan (2020), acknowledged that tourism research is a maturing field with a close association with parent disciplines. Belhassen $\&$ Caton (2009), described that tourism is an infantile area of study that is highly influenced by other disciplines and research traditions. There are many ways of understanding the epistemology and knowledge structure of a discipline. The most popular being the analysis of its scholarly research and publications. Many researchers have put many efforts during the last two decades in determining the most productive and influential scholars, institutions and publications, ranking of tourism journals, individual researchers, and citation counts (Jamal et al., 2008; McKercher, 2008; Park et al., 2011; Schmidgall et al., 2007; Zhao \& Ritchie, 2007). There is a bibliometric analysis of studies in WT that are either conducted country-wise, or that have been conducted in the past (Cong et al., 2017; Vaske et al., 2006). However, in the recent past, there have been no studies that analyze the specialized areas of WT research globally.

In this context, the present study believes that research on WT is fragmented and eclectic. Hence, it needs a systematic review of the present state, the main emerging contributions' thrust areas, identification of critical research areas in WT, the areas that have inadequate research in WT, new subject areas, and citation patterns in WT research. Hence, this represents the context in which our research aims to contribute towards advancing the literature by carrying out a bibliometric analysis of the "WT" concept, seeking to grasp the research already undertaken.

The present study will be relevant to both, academicians and practitioners. Academicians will be benefited by understanding the new trends, emerging areas, developments, and an overview of research from the past two decades in the area of WT. The insights into the present study can give directions to and pave the way for future research. It is also essential for practitioners and policymakers as they require more information to facilitate their decision-making and actions in the area of tourism 392 
development that could improve the competitiveness, innovations of firms and destinations, conservation of the environment, patrimony to next generations, and development of quality of economic and social life of the destination community. Thus, this study is an attempt to answer three research questions. These are as follows:

RQ1: What is the current state of the knowledge base/structure of WT?

RQ2: Which research front/conceptual structure of WT is most popular and where are the academics lacking?

RQ3: What is the shape of the social network structure (based on authors, institutes, and countries) of the WT researchers' community?

\section{LITERATURE REVIEW}

\section{1) WILDLIFE IN TOURISM}

Wildlife tourism is mostly non-consumptive nowadays, including activities like viewing, photography, touching, and feeding, in contrast to killing, hunting, and recreational fishing (Auster et al., 2020).

"Wildlife tourism is based on the tourist encounter with undomesticated animals. These encounters could be either with animal's natural environment or captivity."

In economics, these classifications of WT can be considered a "product-market" with similar patterns of benefits to a group of customers. However, WT has positive impacts like the development of a community and funding for protecting the environment and habitats. In contrast, it also negatively impacts the environment, host communities, and animals. Thus, WTTC/WTO and other organizations are urging for sustainable development.

Wildlife tourism has grown in recent years and is continuing to grow. In this growth trajectory, WT has taken diverse forms like wildlife watching, captive wildlife, hunting and fishing tourism, and collection and conservation of animals (Auster et al., 2020). The 
number of tourists who specifically want to see wildlife is increasing; these tourists display a wide range of ages, socioeconomic backgrounds, and motivations (Reynolds and Braithwaite, 2001; Khanra et al., 2021). We know the importance of WT and how its experience contributes to the consciousness of the human spirit. Non-consumptive WT can be considered a useful tool for engaging people with nature, to make them understand why nature is important to human beings, and assess how memorable experiences with wildlife and the environment can change the thinking of humankind (Ballantyne et al., 2011; Orams, 2002; Auster et al., 2020). Further, Orams, (2002) claims that there is a direct relationship between the health of the natural world and the mind and that people could suffer from "nature-deficit disorder."

Local communities near WT destinations depend on the revenue generated from tourist arrivals. This revenue contributes to the development of local communities and the conservation of wildlife. It is also observed from some studies that revenue is lost due to the illegal killing of elephants in Africa. Thus, a well-established tourism system should be designed to prevent illegal hunting and contribute to the conservation of wildlife. Local communities' attitude depends on different circumstances such as economic dependence on tourism, socio-demographic variables, proximity to attractions, and attachment to the area's culture. The success of WT depends on the positive attitude of host communities towards sustainability and conservation. This can be achieved through involvement, participation, and collaboration of host communities in the development of the region (Liu \& Li, 2020; Bilynets \& Cvelbar, 2020).

The impacts of WT on the environment and animals are addressed with the creation of protected areas by governments globally. These protected areas are attractive and resources for WT. On the contrary, the conservation of animals through WT has not always been having a positive relationship, and, on the other hand, there is a growing concern for sustainability in protected areas. The disturbance through tourism is reflected through altered behavior, altered vigor and productivity, changes in abundance, distribution, and population of species, and changes in the interaction of wildlife communities (Knight, 2010; Winter, 2020).

Wildlife tourism experience gives visitors education and knowledge about animals/species and contributes to the sustainable management of the environment. It 
will not only add to the education aspect of visitors but also change the behavior of visitors towards wildlife. It can also add to the visitor's satisfaction and attitude towards wildlife. Ballantyn et al. (2011) have developed a conceptual framework in understanding how the visitors' experience can affect their attitude, understanding, and actions in relation to the natural environment. The analysis identified four levels of visitors' response to wildlife experiences, namely, sensory impressions, emotional affinity, reflective response, and behavioral response. Ballantyn et al. (2011) has examined and found that tourist experiences are strongly mediated with humankind and nature by the use of jeeps, fences, hides, and trails. He has also investigated the essential ingredients for eliciting tourist memories such as landscape, touch, sound, "smell-scapes," and multisensory facets that make experiences more memorable.

The large base of wildlife literature studies can majorly be categorized into conservation and sustainability, planning and development, economic views, and impacts on the host community, attitude and perceptional studies on tourist experiences (Ballantyn et al. 2011), and so on. Studies on WT can also be divided into conceptual studies and empirical studies; however, the majority of the studies are conceptual. Further, there are inadequate studies that talk about the overall literature on WT.

\section{2) BIBLIOMETRIC STUDIES IN TOURISM}

The bibliometric analysis is also employed in tourism literature to evaluate journals and authors who published them (Barrios et al., 2008; Hall, 2011; Tokić \& Tokić, 2017; Zhang et al., 2015; Zopiatis et al., 2015; Kaurav, et. al., 2020; Khanra, et. al., 2021). Koseoglu et al., (2016) classified bibliometric analysis of tourism literature into six categories, namely, country analysis, discipline analysis, article identification, content analysis, ranking studies, and citation analysis. However, there are no studies found on bibliometric analysis on WT globally (limited to knowledge of researchers based on data from the WoS. Hence, the present study seeks to examine the co-occurrence and co-citation analysis of WT literature.

The bibliometric study is defined as "the quantitative study of physical published units, or bibliographic units, or the surrogates for either" (Broadus, 1987). In other words, the 395 
bibliometric study analyzes how the disciplines are evolved based on intellectual, conceptual, and social structures (Zupic \& Čater, 2015). The analysis focuses on the scholarly research outputs, a phenomenon studied, methodology, sampling design, and statistical techniques from previously published research articles in research journals and conference proceedings (Cobo et al., 2011).

The bibliometric approach assesses the performance of the research publications, scholars, and institutions. Further, it gives an overall picture of the structure and dynamics of the area of study (Cobo et al., 2011). Therefore, bibliometric analysis can answer several questions like:

(a) How did the discipline evolve and what is the intellectual structure?

(b) What is the academic collaboration in the discipline/subject?

(c) What are the conceptual composition and development of the discipline?

(d) What is the best way to assess research output?

(e) How to examine the influence of researchers and institutions?

(f) What are the trends in the discipline, the important themes, research variables, the methodology adopted, and sampling methods used? (Koseoglu et al., 2016; Nerur, Rasheed, \& Natarajan, 2008; Zupic \& Čater, 2015; Khanra, et. al., 2021).

Benckendorff \& Zehrer, (2013) described that bibliometric methods could be classified into two ways: (a) evaluative techniques; and (b) relational techniques. The evaluative techniques assess the effect (in terms of citations and usage) of academic studies by employing productive measures and metrics (Hall, 2011). At the same time, relational techniques deal with examining association among the published research, by considering the different categories of keywords, authors, an affiliation of authors, and citations. This technique helps researchers in describing the intellectual structure of the discipline, the domain social structure, and the advent of trends in research areas (Leydesdorff \& Vaughan, 2006; Liwen \& Jingkun, 2014; Nerur, Rasheed, \& Pandey 2016; Pilkington \& Lawton, 2014; Ronda-Pupo \& Guerras-Martin, 2012).

Bibliometric analysis of research publications can be conducted broadly through five different methods. The first three methods are citation analysis, co-citation analysis, and bibliographic coupling that uses the citation data. The next two methods are co-author analysis and co-word analysis, wherein co-author analysis uses co-authorship data that 
can derive a measure of collaboration, and co-word analysis deals with concepts that cooccur, drawn from document titles, keywords, and abstracts.

A majority of bibliometric studies conduct citation analysis of the research field by listing the most cited publications, journals, and authors. Assuming that the most cited publications are considered necessary, this proposition is based on the assumption that authors cite a research publication when they consider it as crucial for their research work. Further, the citation analysis can give information regarding the relative impact of publications; however, citation analysis can't determine the networks and associations among research scholars (Üsdiken \& Pasadeos, 1995; Liu \& Li, 2020).

Co-citation analysis can be explained as the occurrence with which two units are cited together (Small, 1973). Co-citation analysis rests on the assumption that the more two items are cited together, the more it is likely that their content is co-related. There are different types of co-citation analyses-author co-citation analysis, journal co-citation analysis, and document co-citation analysis (McCain, 1990; White \& Griffith, 1981; White \& McCain, 1998).

Bibliographic coupling is a similarity measure like co-citation analysis, where two articles are bibliographically coupled when both the articles are cited simultaneously in a third article. The more the number of times the two articles are cited together, the higher the connection between them. It can be interpreted that when two documents are highly co-cited, it means individual documents are also highly cited (Jarneving, 2005). Hence, it can be determined that co-citation is essential for researchers citing them.

Co-author analysis assesses the social structure created by collaborating on research articles by the researchers (Acedo et al., 2006). A collaboration between the researchers is established when researchers publish a research article jointly (Lu \& Wolfram, 2012). Hence, it is presumed that co-authoring a research publication is a measure of collaboration. Co-author analysis reveals the social ties among researchers more than any other relatedness measure.

Co-word analysis is a content analysis technique that utilizes words in documents as certain relationships between ideas (Callon et al., 1983) The concept underlying co-word analysis is that when a common word exists in documents, it can be understood that the concepts behind those words could be associated. Co-word analysis is the only method 
to consider the content of the publication for similarity measure. In contrast, other methods like co-occurrence analysis compare the documents indirectly through citations.

\section{METHODOLOGY AND DATA}

As it is impossible to access all scientific production in the thematic area, the lack of availability, credibility, and reliability of information limit the bibliometric analysis (ÁlvarezGarcía et al., 2018; Álvarez-García et al., 2019). Therefore, the search criteria for the study were based on the scope of the review in the thematic (selected, i.e. WT) area. The WoS, which is one of the most popular and well-accepted multidisciplinary databases of the world, was chosen for this study (Chang \& McAleer, 2012; Álvarez-García et al., 2018; Lima Santos, et al., 2020). WoS database was chosen to list high-quality scientific papers on rural tourism because: (a) it has a good selection and coverage of publications (Álvarez-García et al., 2018); (b) it applies rigorous quality standards for scientific material selection (Falagas et al., 2008); (c) it provides advance options to refine the information of database search results (Falagas et al., 2008); and (d) it provides access to download the scientific material details from the database as metadata.

The study conducted a bibliometric review of literature related to WT using VOS viewer software version 1.6.5. For constructing the bibliometric maps, clusters, and their reference networks, the methodologies have been adopted from Cardoso et al., (2020), Perianes-Rodriguez et al., (2016), Triantafyllou et al., (2020), and Van Eck \& Waltman, (2010). Nowadays, the VOS viewer is more widely used in the bibliometric analysis as compared to the recent past (Blanco-Mesa et al., 2017), and it can offer formation and association of authors, countries, journals, and institutions. This study focuses on coauthorship analysis, co-occurrence analysis, co-citation analysis, and bibliographic coupling of WT using the VOS viewer software. These analyses are widely employed metrics used in the bibliometric literature (Garrigos-Simon et al., 2018; Mulet-Forteza et al., 2018; Merigó et al., 2020).

This research paper is bibliometric evaluative and bibliometric relational; the classification is offered by Koseoglu et al. (2016). The data collection includes only research articles while reviews, conference reports, proceedings, editorials, notes, letters, 
and errata were excluded while collecting data. The data collection was carried out using the most widely recognized international indexing databases, WoS because WoS is of the highest standards and extensive coverage comparatively. WoS is an old database with a wider range of collection of research documents (Boyle \& Sherman, 2006; McKercher, 2008). The authors used the following keywords and criteria for extracting the data (Figure 1):

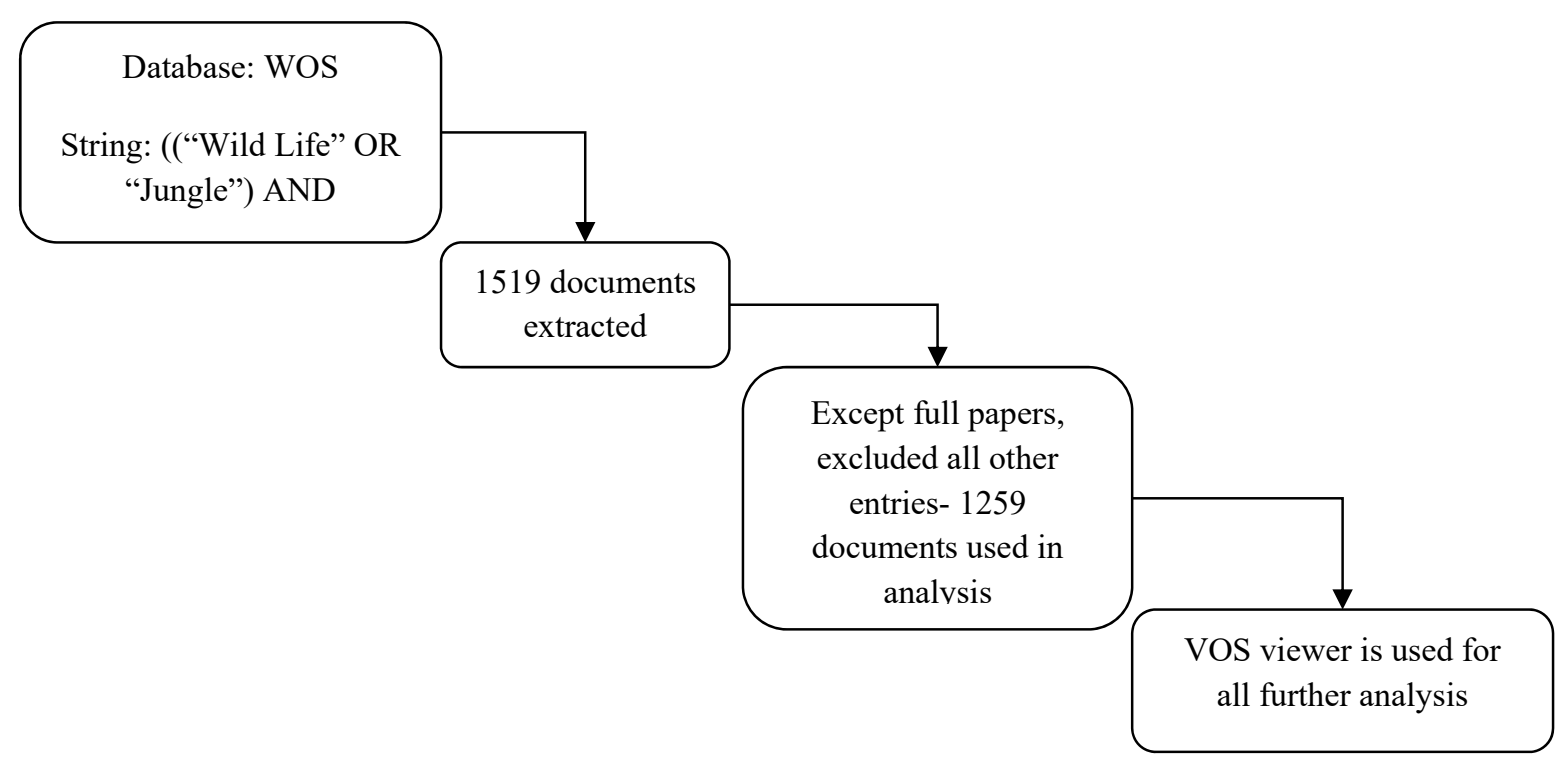

Figure 1: Criteria and framework of inclusion and exclusion of papers

The data collection using these keywords resulted in 1,519 documents. The search was performed for a publication period from 1990 to 2020 (Table 1 for classification details of the papers).

\begin{tabular}{lc}
\hline Description & Results \\
MAIN INFORMATION ABOUT DATA & $1990: 2020$ \\
\hline Timespan & 568 \\
Sources (Journals, Books, Etc.) & 1,519 \\
Documents & 7.57 \\
Average Years From Publication & 17.39 \\
Average Citations Per Documents & 1.839 \\
Average Citations Per Year Per Doc & 57,200 \\
References & \\
DOCUMENT TYPES & 1,259 \\
\hline Articles &
\end{tabular}




\begin{tabular}{lc}
\hline DOCUMENT CONTENTS & \\
\hline Keywords Plus (ID) & 2,750 \\
Author's Keywords (DE) & 4,146 \\
\hline AUTHORS & \\
\hline Authors & 3,980 \\
Author Appearances & 5,036 \\
Authors Of Single-Authored Documents & 283 \\
Authors Of Multi-Authored Documents & 3,697 \\
\hline AUTHORS COLLABORATION & 323 \\
Single-Authored Documents & 0.382 \\
Documents Per Author & 2.62 \\
Authors Per Document & 3.32 \\
Co-Authors Per Documents & 3.09 \\
\hline Collaboration Index & \\
\hline \multicolumn{2}{l}{ Table 1: Main demographic information related to the search results } \\
$\quad$ Source: Authors
\end{tabular}

\section{RESULTS}

Figure 3 shows the evolution of publications in the field of WT from 2000 to 2020 . A total of 1,259 research articles on WT have 26,425 citations with 17.4 average citations per document, which were collected from SCOPUS and WOS for analysis. Out of 1,259, only 499 (32.8\%) articles had citations, while the remaining articles didn't have citations. A majority of the documents were articles ( $N=1,259,82.8 \%)$ followed by proceeding papers $(\mathrm{N}=91,5.9 \%)$. The documents collected in the domain of WT have a total of 2,750 keywords and 4,146 author keywords. Among a total of 3,980 authors, 283 are single authors and 3,697 are authors of multi-authored documents who contributed through their research to WT. Further, it was found that there were 0.38 documents per author, 2.62 authors per document, and 3.32 co-authors per document. The C-Index in the domain of WT is at 3.09, which reveals the level of collaboration among authors. The details and structure of this study have been more clearly explained in Figure 2. 


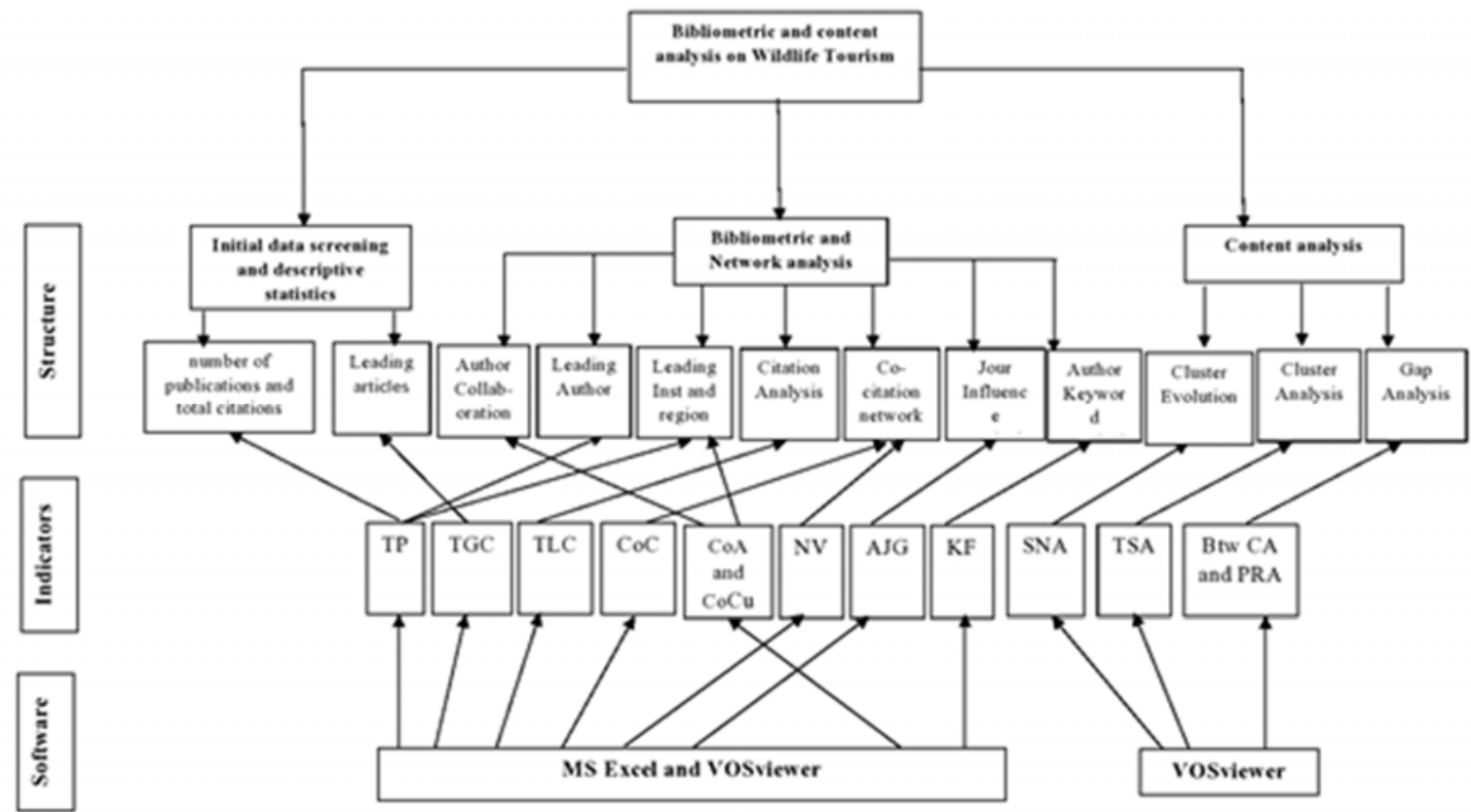

Figure 2: Systematic structure of study | Source: Authors

Note TP=Total publications, $\mathrm{CoC}=\mathrm{Co}$-citation count, $\mathrm{CoA}=\mathrm{Co}$-authorship, $\mathrm{CoCu}=$ Collaboration of countries, TGC=Total global citation, TLC=Total local citation, KF=Author key-word frequency, AJG=Academic journal guide, $\mathrm{SNA}=$ Social network analysis, NV=Network visualization, BtwCA=Between centrality analysis, PRA=Page rank analysis, TSA=Thematic structure analysis

Further, the average $\mathrm{h}$-index of the articles mentioned earlier is at 73 . The articles published from 2002 to 2005 were lowest compared to other periods. Publications in WT have geared up from 2012 to 2020 . Further, we observed a sustainable growth in publications from 2016 to 2019. The citations in WT increased linearly from 2005 to 2019, resembling the quality of research articles published during the mentioned period (Figure 3). 


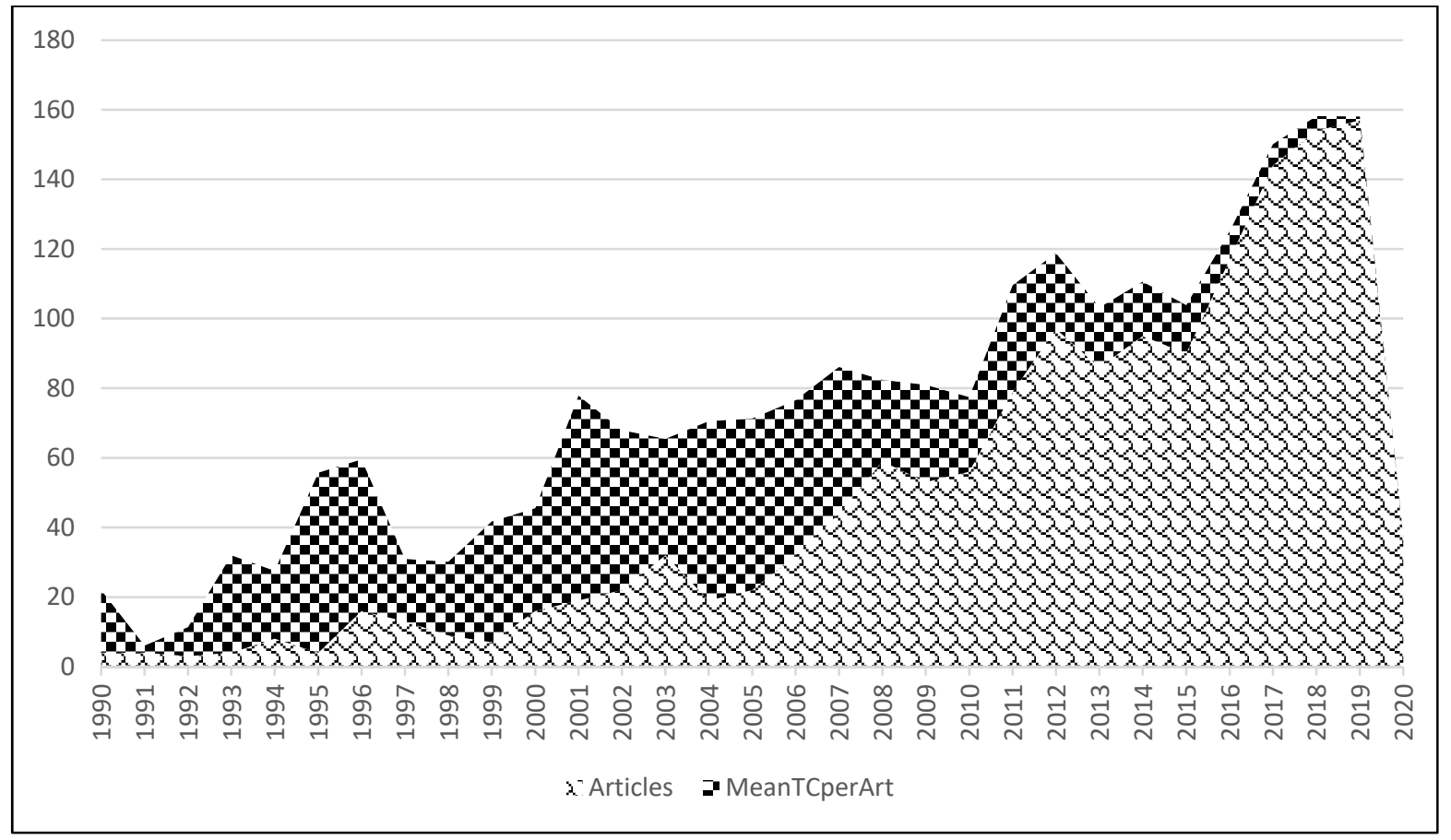

Figure 3: Comparison between the total number of publications and mean total citations (year-wise) Source: Authors

\section{1) TOP-CITED ARTICLES ON WILDLIFE TOURISM}

Table 2 indicates the ten most-cited articles on WT. To create this table, the ordinal ranking method was applied. The most prominent paper discusses the impact of microplastics in the deep-sea on wildlife, tourism, and shipping. The paper is a quantitative study conducted by collecting samples from the Atlantic Ocean, the Mediterranean Sea, and the Indian Ocean for analyzing levels of micro-plastics (Woodall et al., 2014). The second-most cited article discusses the social and environmental impacts, and the responses and indicators of the mainstream tourism sector worldwide in five categories, namely, population, peace, prosperity, pollution, and protection (Buckley, 2012). The third most-cited article evaluates the impact of vessel activity on bottle-nose dolphins in Shark Bay, Australia. Bejder et al. (2006) and Weaver \& Lawton (2007) had consolidated the literature pertaining to eco-tourism in the perspective of giving attention to critical areas such as quality control, the industry, and external environments or institutions after examining the literature of two decades. 
Rank Article particulars

1 Woodall, L.C.; Sanchez-Vidal, A.; Canals, M.; Paterson, G.L.; Coppock, R.; Sleight, V.; Calafat, A.; Rogers, A.D.; Narayanaswamy, B.E.; Thompson, R.C. The deep sea is a major sink for microplastic debris. Royal Society Open Science, Vol. 1, No 4, 2014, pp. 140317.

2 Buckley, R. Sustainable tourism: Research and reality. Annals of Tourism Research, Vol 39, No 2, 2012, pp. 528546.

3 Bejder, L.; Samuels, A.; Whitehead, H.; Gales, N.; Mann, J.; Connor, R.; Heithaus, M.; Watson-Capps, J.; Flaherty, C.; Krützen, $M$. Decline in relative abundance of bottlenose dolphins exposed to long-term disturbance. Conservation Biology, Vol. 20, No 6, 2006, pp. 1791-1798.

4 Weaver, D.B.; Lawton, L.J. Twenty years on: The state of contemporary ecotourism research. Tourism Management, Vol. 28, No 5, 2007, pp. 1168-1179.

5 Orams, M.B. Feeding wildlife as a tourism attraction: A review of issues and impacts. Tourism Management, Vol. 23, No 3, 2002, pp. 281-293.

6 Krüger, $O$. The role of ecotourism in conservation: Panacea or Pandora's box? Biodiversity Conservation, Vol. 14, No 3, 2005, pp. 579-600.

7 Reynolds, P.C.; Braithwaite, D. Towards a conceptual framework for wildlife tourism. Tourism Management, Vol. 22, No 1, 2001, pp. 31-42.

8 Ballantyne, R.; Packer, J.; Sutherland, L.A. Visitors' memories of wildlife tourism: Implications for the design of powerful interpretive experiences. Tourism Management, Vol. 32, No 4, 2011, pp. 770-779.

9 Ballantyne, R.; Packer, J.; Falk, J. Visitors' learning for environmental sustainability: Testing short-and long-term impacts of wildlife tourism experiences using structural equation modelling. Tourism Management, Vol. 32, No 6, 2011, pp. 1243-1252.

10 Müllner, A.; Linsenmair, K.E.; Wikelski, M. Exposure to ecotourism reduces survival and affects stress response in hoatzin chicks (Opisthocomus hoazin). Biological Conservation, Vol. 118, No 4, 2004, pp. 549-558.
Citations Reference

$389 \quad$ (Woodall et

al., 2014)

322 (Buckley, 2012)

308 (Bejder et al., 2006)

264 (Weaver \& Lawton, 2007)

225 (Orams, 2002)

207 (Krüger, 2005)

205 (Reynolds \& Braithwaite, 2001)

202 (Ballantyne, Packer, \& Sutherland, 2011)

197 (Ballantyne, Packer, \& Falk, 2011)

193 (Müllner et al., 2004) Table 2: Ten most-cited research articles on wildlife tourism (as of May 2020) Source: Authors

Orams (2002) highlighted the issues and impacts of wildlife feeding by humans. His pioneering study concluded that there are psychological, social, and economic benefits on the human side; but wildlife has benefitted in very limited cases. Krüger (2005) concluded that prior planning, local involvement, and control measures are the approaches to help eco-tourism in the conservation of wildlife, and is an outcome of examining 251 case studies on eco-tourism from literature. Reynolds \& Braithwaite (2001) 
designed a conceptual framework constituting conservation, animal welfare, visitor satisfaction, and profitability about WT/recreation that can build sustainable tourism.

Ballantyne, et. al., (2011) examined participants' memories of their WT experiences and developed a conceptual framework that could explain how such experiences can lead to long-term changes in conservation behavior. Their study classified the responses of visitors to four marine-based WT spots in South-East Queensland into sensory impressions, emotional affinity, thoughtful response, and behavioral response. Müllner et al. (2004) examined whether eco-tourism-protected habitats had any negative impacts on wildlife. The study investigated the effects of tourists on the reproductive success of hoatzins and the hormonal status of their chicks in Amazon Forest's lakes. It can be observed that the top-cited documents on wildlife literature cover versatile areas like conservation, tourists' responses, eco-tourism, and marine life, amongst many others. Further, the research designs cover quantitative, qualitative, and bibliographic studies.

In a summary, most of the top-cited papers on WT were conceptual and their themes were very diverse-ranging from the sea, sustainability, eco-tourism, human behavior, to other dimensions also. Surprisingly, the journals which published the WT papers are not limited to tourism-related journals. There were several across the borders of the discipline which also accepted papers themed on WT.

\section{2) TOP CITED AUTHORS}

A total of 4,064 authors have published 1,259 research studies on WT. Among these, only 38 authors have a minimum of ten citations, grouped into six clusters. Table 3 consists of a list of the top-cited authors who had published their research studies on WT. Roy, B. and Jan, P. have been the top-cited authors with 791 citations each, followed by Lars, B., with 521 citations. When total publications are grouped into six clusters, the majority of the authors have focused on publications related to WT, conservation, protected areas, tourism development, and sustainable development (cluster 1) (Table 3). 


\begin{tabular}{lcc}
\hline Authors & Citations & Cluster \\
Ballantyne, Roy & 791 & 1 \\
Packer, Jan & 791 & 1 \\
Bejder, Lars & 521 & 2 \\
Buckley, Ralf & 392 & 1 \\
Hughes, Karen & 350 & 1 \\
Moore, Susan A. & 300 & 1 \\
Gallagher, Austin J. & 274 & 2 \\
Karanth, Krithi K. & 270 & 1 \\
Macdonald, David W. & 260 & 1 \\
Braunisch, Veronika & 235 & 2 \\
\hline \multicolumn{2}{c}{ Table 3: List of top-cited authors in wildlife tourism } \\
\multicolumn{2}{c}{ Source: Authors }
\end{tabular}

The top-cited authors and their recent publications on WT are mentioned in Table 4. Buckley, R. is a Professor at Griffith University with the highest number of citations $(15,780)$ and an $\mathrm{H}$-Index of 63 , followed by Professor Ballantyne Roy from the University of Queensland with 10,777 citations and an H-Index of 51. Similarly, Professor Jan Packer (citations 9,138, H-Index 46), Bejder Lars $(806,847)$, Susan A Moore $(896,841)$, Karen Hughes $(397,426)$, Gallagher, Austin J. $(225,626)$, Karanth, Krithi K. $(219,823)$, and Braunisch, Veronika $(229,526)$ have followed the pattern. The number of citations and the $\mathrm{H}$-index of McDonald, David W. was not retrievable from his university's website.

The study finds a very interesting aspect regarding the top-cited authors. It is observed that a majority of authors belong to Australia. Hence, it can be concluded that major research studies in WT are happening in Australia. It is also observed that Buckley, Professor Ballantyne Roy, Professor Jan Packer, and Karen Hughes are associated with the University of Queensland. Further, Professor Ballantyne Roy and Professor Jan Packer have joint authorship in the field of conservation and WT (for details see Figure 4). 


\begin{tabular}{|c|c|c|c|c|c|c|}
\hline Author & $\begin{array}{l}\text { Title of Recent Publication } \\
\text { in Wildlife Tourism }\end{array}$ & Affiliation & $\begin{array}{l}\text { H- } \\
\text { Index } \\
\text { of the } \\
\text { author }\end{array}$ & Reference & Journal & $\begin{array}{l}\text { Total } \\
\text { Citations } \\
\text { of } \\
\text { author* }\end{array}$ \\
\hline $\begin{array}{l}\text { Buckley, } \\
\text { Ralf }\end{array}$ & $\begin{array}{l}\text { Economic value of protected areas } \\
\text { via visitor mental health } \\
10.1038 / \mathrm{s} 41467-019-13619-\mathrm{y}\end{array}$ & $\begin{array}{l}\text { Griffith } \\
\text { University }\end{array}$ & 63 & $\begin{array}{l}\text { (Buckley et } \\
\text { al., 2019) }\end{array}$ & $\begin{array}{l}\text { Nature } \\
\text { Communi } \\
\text { cations }\end{array}$ & 15780 \\
\hline $\begin{array}{l}\text { Ballantyne, } \\
\text { Roy }\end{array}$ & $\begin{array}{l}\text { Exploring the factors that influence } \\
\text { zoo visitors' perceptions of the well- } \\
\text { being of gorillas: implications for } \\
\text { zoo exhibit interpretation } \\
10.1080 / 10645578.2018 .1503878\end{array}$ & $\begin{array}{l}\text { University } \\
\text { of Queens } \\
\text { land }\end{array}$ & 51 & $\begin{array}{l}\text { (Packer et } \\
\text { al., 2018) }\end{array}$ & $\begin{array}{l}\text { Visitor } \\
\text { Studies }\end{array}$ & 10,777 \\
\hline $\begin{array}{l}\text { Packer, } \\
\text { Jan }\end{array}$ & $\begin{array}{l}\text { Visitors' learning for environmental } \\
\text { sustainability: Testing short- and } \\
\text { long-term impacts of wildlife tourism } \\
\text { experiences using structural } \\
\text { equation modeling. } \\
\text { 10.1080/10645578.2018.1503878 }\end{array}$ & $\begin{array}{l}\text { University } \\
\text { of Queens } \\
\text { land }\end{array}$ & 46 & $\begin{array}{l}\text { (Ballantyne, } \\
\text { Packer, \& } \\
\text { Falk, 2011) }\end{array}$ & $\begin{array}{c}\text { Tourism } \\
\text { Manage } \\
\text { ment }\end{array}$ & 9138 \\
\hline $\begin{array}{l}\text { Bejder, } \\
\text { Lars }\end{array}$ & $\begin{array}{l}\text { Decline in relative abundance of } \\
\text { bottlenose dolphins exposed to } \\
\text { long-term disturbance } \\
\text { 10.1111/j.1523-1739.2006.00540.x }\end{array}$ & $\begin{array}{l}\text { Dalhousie } \\
\text { University }\end{array}$ & 47 & $\begin{array}{l}\text { (Bejder et } \\
\text { al., 2006) }\end{array}$ & $\begin{array}{l}\text { Conserva } \\
\text { tion } \\
\text { Biology }\end{array}$ & 8068 \\
\hline $\begin{array}{l}\text { Moore, } \\
\text { Susan A }\end{array}$ & $\begin{array}{l}\text { Re-thinking visitor loyalty at 'once in } \\
\text { a lifetime' nature-based tourism } \\
\text { destinations: Empirical evidence } \\
\text { from Purnululu National Park, } \\
\text { Australia } \\
\text { 10.1016/j.jort.2016.08.002 }\end{array}$ & $\begin{array}{l}\text { Murdoch } \\
\text { University }\end{array}$ & 41 & $\begin{array}{l}\text { (Pinkus et } \\
\text { al., 2016) }\end{array}$ & $\begin{array}{l}\text { Journal } \\
\text { of } \\
\text { outdoor } \\
\text { recreatio } \\
\mathrm{n} \text { and } \\
\text { tourism }\end{array}$ & 8968 \\
\hline $\begin{array}{l}\text { Hughes, } \\
\text { Karen }\end{array}$ & $\begin{array}{l}\text { Effective conservation behaviours } \\
\text { for protecting marine environments: } \\
\text { the views of the experts } \\
10.1080 / 09669582.2020 .1741597\end{array}$ & $\begin{array}{l}\text { University } \\
\text { of Queens } \\
\text { land }\end{array}$ & 26 & $\begin{array}{l}\text { (Hofman et } \\
\text { al., 2020) }\end{array}$ & $\begin{array}{l}\text { Journal } \\
\text { of } \\
\text { Sustaina } \\
\text { ble } \\
\text { Tourism }\end{array}$ & 3974 \\
\hline $\begin{array}{l}\text { Gallagher, } \\
\text { Austin J. }\end{array}$ & $\begin{array}{l}\text { Emerging challenges to shark- } \\
\text { diving tourism } \\
\text { 10.1016/j.marpol.2018.07.009 }\end{array}$ & $\begin{array}{l}\text { University } \\
\text { of Miami }\end{array}$ & 26 & $\begin{array}{c}\text { (Gallagher \& } \\
\text { Huveneers, } \\
\text { 2018) }\end{array}$ & $\begin{array}{l}\text { Marine } \\
\text { Policy }\end{array}$ & 2256 \\
\hline $\begin{array}{l}\text { Karanth, } \\
\text { Krithi K. }\end{array}$ & $\begin{array}{l}\text { Patterns of human-wildlife conflicts } \\
\text { and compensation: Insights from } \\
\text { Western Ghats protected areas } \\
\text { 10.1016/j.biocon. } 2013.06 .027\end{array}$ & $\begin{array}{l}\text { Centre for } \\
\text { Wildlife } \\
\text { Studies }\end{array}$ & 23 & $\begin{array}{l}\text { (Karanth et } \\
\text { al., 2013) }\end{array}$ & $\begin{array}{l}\text { Biological } \\
\text { Conserva } \\
\quad \text { tion }\end{array}$ & 2198 \\
\hline $\begin{array}{l}\text { Macdonald, } \\
\text { David W. }\end{array}$ & $\begin{array}{l}\text { The Customer Isn't Always Right- } \\
\text { Conservation and Animal Welfare } \\
\text { Implications of the Increasing } \\
\text { Demand for Wildlife Tourism } \\
\text { 10.1371/journal.pone.0138939 }\end{array}$ & $\begin{array}{l}\text { University } \\
\text { of Oxford }\end{array}$ & NA & $\begin{array}{l}\text { (Moorhouse } \\
\text { et al., 2015) }\end{array}$ & $\begin{array}{l}\text { PLOS } \\
\text { ONE }\end{array}$ & NA \\
\hline $\begin{array}{l}\text { Braunisch, } \\
\text { Veronika }\end{array}$ & $\begin{array}{l}\text { Habitat suitability modulates the } \\
\text { response of wildlife to human } \\
\text { recreation } \\
10.1016 / \text { j.biocon. } 2018.08 .018\end{array}$ & $\begin{array}{l}\text { University } \\
\text { of Bern }\end{array}$ & 26 & $\begin{array}{l}\text { (Coppes et } \\
\text { al., 2018) }\end{array}$ & $\begin{array}{l}\text { Biological } \\
\text { conservat } \\
\text { ion }\end{array}$ & 2295 \\
\hline
\end{tabular}

${ }^{*}$ Overall citations of author

Table 4: List of the top-cited authors' recent publications on wildlife tourism Source: Authors 


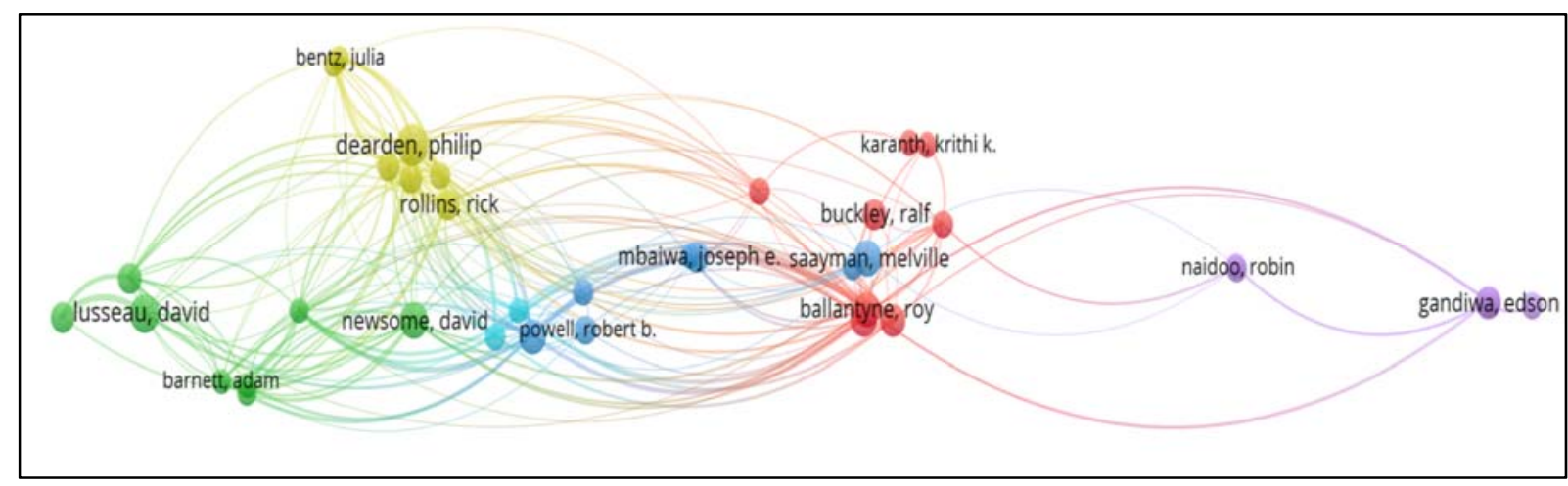

Figure 4: Structural relationship among the top-cited authors Source: Authors

\section{3) LIST OF TOP-CITATION JOURNALS}

Table 5 lists the top journals in order of their citations in WT literature. Each node explains the activity and the number of published articles. Further, citation frequency can be inferred from the distance between each journal. A total of 568 journals were identified to have published literature on WT and were clustered into nine groups (each group with a different color) in Figure 5. Link strength and number citations divide the journals into different clusters. Of these journals, only 60 journals have more than 10 citations in WT literature. The first cluster has 17 journals related to conservation, ecology, environment, and biodiversity. The second cluster has 11 journals related to biological conservation, ecological, environmental and wildlife management, and wildlife biology. The third cluster has 9 journals related to WT, recreation, tourism management, and sustainability. The remaining clusters have 23 journals related to marine, animal conservation, economics, and ocean and coastal management. Table 5 indicates the most cited journals (sources). To create this table, the ordinal ranking method was applied.

Out of 1,259 publications on WT, the twelve top-cited journals mentioned next, published a total of 347 documents $(22.8 \%)$. Further, the three top-cited journals published $4 \%$ of the documents relatively.

According to citations and documents in WT and link strength, Tourism Management Journal (citations 3,004, documents 67, and link strength 520) has led the group of journals publishing studies on WT, followed by Biological Conservation (citations 1,943, documents 16, and link strength 430), Journal of Sustainable Tourism (citations 1,299, 
documents 63, and link strength 274), Environmental Conservation (citations 1,128, documents 23, and link strength 135), Conservation Biology (citations 1,040, documents 11, and link strength 77), Environmental Management (citations 841, documents 19, and link strength 114), Annals of Tourism Research (citations 708, documents 12, and link strength 50), Biodiversity and Conservation (citations 629, documents 20, and link strength 107), Plos One (citations 629, documents 33 , and link strength 161), Journal of Wildlife Management (citations 455, documents 16, and link strength 49), Marine Ecology Progress Series (citations 438, documents 9, and link strength 120), and Journal of Environmental Management (citation 435, documents 13, and link strength 121).

\begin{tabular}{clcccc}
\hline Rank & Name of the Journal & Citations & Documents & Total Link Strength & Cluster \\
\hline $\mathbf{1}$ & Tourism Management & 3,004 & 67 & 520 & 3 \\
$\mathbf{2}$ & Biological Conservation & 1,943 & 61 & 430 & 2 \\
$\mathbf{3}$ & Journal of Sustainable Tourism & 1,299 & 63 & 274 & 1 \\
$\mathbf{4}$ & Environmental Conservation & 1,128 & 23 & 135 & 1 \\
$\mathbf{5}$ & Conservation Biology & 1,040 & 11 & 77 & 2 \\
$\mathbf{6}$ & Environmental Management & 841 & 19 & 114 & 1 \\
$\mathbf{7}$ & Annals of Tourism Research & 708 & 12 & 50 & 3 \\
$\mathbf{8}$ & Biodiversity and Conservation & 629 & 20 & 107 & 1 \\
$\mathbf{9}$ & Plos One & 629 & 33 & 161 & 6 \\
$\mathbf{1 0}$ & Journal of Wildlife Management & 455 & 16 & 49 & 2 \\
\hline \multicolumn{5}{c}{ Table 5: Top citation journals (sources) } \\
\multicolumn{5}{c}{ Source: Authors }
\end{tabular}




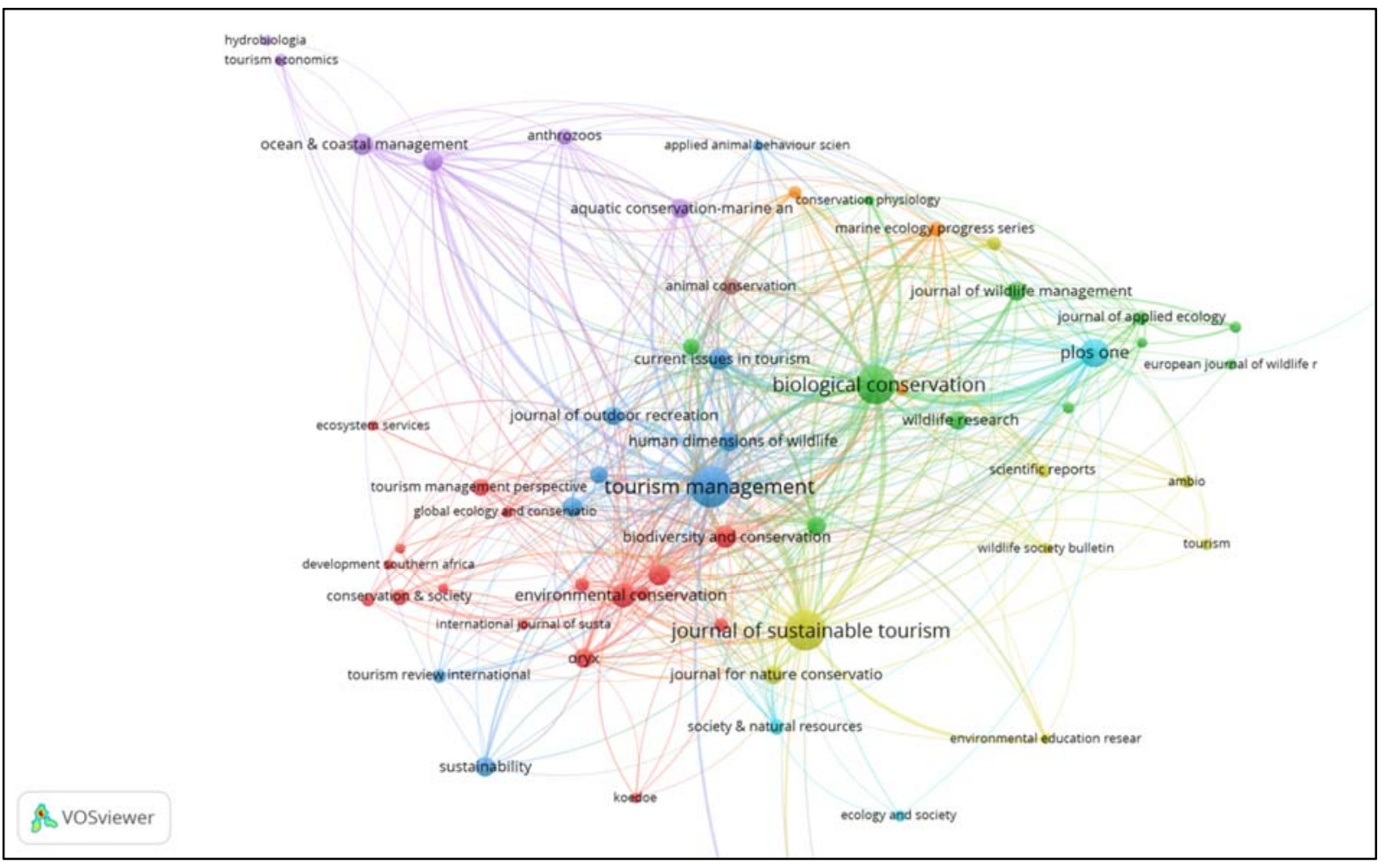

Figure 5: Structural relationship among the top-cited journals Source: Authors

From these top-cited journals, as listed in Table 5, it can be observed that the majority of journals belong to the first three clusters, as mentioned earlier. Journal of Sustainable Tourism (citations 1,299 and link strength 520), Environmental Conservation (citations 1,128 and link strength 135), Environmental Management (citations 841 and link strength 114), and Biodiversity and Conservation (citations 629 and link strength 107) belong to cluster one. Biological Conservation (citations 1,943 and link strength 430), Conservation Biology (citations 1,040 and link strength 77), Journal of Wildlife Management (citations 455 and link strength 49), and Journal of Environmental Management (citations 841 and link strength 111) belong to cluster two. Tourism Management (citations 3,004 and link strength 520), and Annals of Tourism Research (citations 708 and link strength 50) belong to cluster three.

Hence, it can be summarized that top-cited literature in WT is majorly available in Tourism Management, followed by the Journal of Sustainable Tourism and Annals of Tourism Research. Further, it can be observed that conservation and sustainability 
studies in WT are published in Biological Conservation, followed by Environmental Conservation and Biology Conservation. It is also observed that among all the journal lists, Tourism Management takes the first place since it has a high link strength and number of citations.

\section{4) BIBLIOGRAPHIC COUPLING}

This analysis identifies the group of documents with common references (For example, two documents $A$ and $B$ are grouped when they cite document $C$ ). This analyses another perspective of understanding the relatedness of the author by examining bibliographic coupling. The analysis is summarized in Table 6. For developing this matrix, an ordinal ranking method was applied. Observing the strength and citations, the rank was led by Dearden Philip (link strength 11,213, citations 222, and documents 13), Huveneers Charlie (link strength 10,915, citations 103, and documents 10), Newsome David (link strength 8,131, citations 133, and documents 11), Lusseau David (link strength 7,643, citations 216, and documents 12), and Bejder Lars (link strength 7,229, citations 521, and documents 8).

Among the 4,064 authors, 378 have a minimum of two documents with common references. These authors with bibliographic coupling are grouped into 12 clusters. It can be observed from Table 6 that the top-ten authors belong to clusters three, four, and five. The top authors, as mentioned next, have focused their research mainly on tourist satisfaction, behavioral studies, white sharks and whale watching, wild animals, and protected areas.

It is found that Dearden Philip, Huveneers Charlie, and David Newsome, the topauthors with high relatedness in WT literature, belong to the field of sciences and their studies are related to the conservation of rare species, animal behavior, and the environmental impacts of WT. Dearden Philip is associated with the University of Victoria, working as a Professor in the Geography department and his research interests lie in the areas of conservation, protected areas, marine, and tropics. Huveneers Charlie is an Associate Professor at Flinders University and his area of research interest is fish biology and ecology. Even though these two authors belong to the field of sciences, their studies 
in conservation, protected areas, sustainability, and ecology are a part of WT literature. David Newsome (associated with Murdoch University) has a research interest in ecotourism, WT, geo-tourism, and protected area management. His studies address the impacts and management of destinations and sustainability pertaining to WT. Hence, it can be understood that the science faculty is displaying a higher level of relatedness in WT studies as compared to the tourism faculty. It could also be inferred that collaboration is a way of sharing knowledge and improving research performance for the academic world.

\begin{tabular}{clcccc} 
Rank & Author & Citations & Link Strength & Documents & Cluster \\
\hline $\mathbf{1}$ & Dearden Philip & 222 & 11213 & 13 & 3 \\
$\mathbf{2}$ & Huveneers Charlie & 103 & 10915 & 10 & 3 \\
$\mathbf{3}$ & Newsome David & 133 & 8131 & 11 & 4 \\
$\mathbf{4}$ & Lusseau David & 216 & 7643 & 12 & 5 \\
$\mathbf{5}$ & Bejder Lars & 521 & 7229 & 8 & 5 \\
$\mathbf{6}$ & Rollins Rick & 165 & 7008 & 8 & 3 \\
$\mathbf{7}$ & Apps Kirin & 59 & 6981 & 5 & 3 \\
$\mathbf{8}$ & Gallagher Austin J & 274 & 6972 & 5 & 3 \\
$\mathbf{9}$ & Hammerschlag Neil & 268 & 6355 & 4 & 3 \\
$\mathbf{1 0}$ & Christiansen Fredrik & 154 & 6275 & 8 & 5 \\
\hline
\end{tabular}

Table 6: Bibliographic coupling of references in wildlife tourism

Source: Authors

\section{5) KEYWORD ANALYSIS}

Keyword analysis involves the observation of the most frequently used words in WT literature. This analysis is done through keyword co-occurrence analysis. This analysis focuses on keywords appearing in the abstract section. The objective of keyword analysis is to visualize the trends of the most important research areas in the field of WT. The keyword analysis technique lists out the number of documents in which two keywords appear together. Out of 6,033 keywords in WT literature with a minimum occurrence of 15 times, 111 keywords were identified. These identified keywords are formed into five clusters. The size of the node represents high occurrence and the lines between the nodes represent the frequency of occurrence of the two words together in different articles. The smaller the distance between the keywords, the significantly higher the relationship between these two words relative to other co-occurring words. The different colors represent different clusters of keywords. The top-ten keywords with high link 
strength and occurrence and the clusters formed are summarized in Table 7. This table was created on the basis of the ordinal ranking method.

\begin{tabular}{clccc} 
Rank & Key Words & Occurrences & Total Link Strength & Cluster \\
\hline $\mathbf{1}$ & Conservation & 350 & 1547 & 1 \\
$\mathbf{2}$ & Tourism & 397 & 1472 & 3 \\
$\mathbf{3}$ & Wildlife & 282 & 1256 & 1 \\
$\mathbf{4}$ & Management & 244 & 1171 & 2 \\
$\mathbf{5}$ & Eco-tourism & 211 & 964 & 2 \\
$\mathbf{6}$ & Protected Areas & 149 & 767 & 1 \\
$\mathbf{7}$ & Wildlife Tourism & 184 & 710 & 2 \\
$\mathbf{8}$ & Attitudes & 111 & 589 & 1 \\
$\mathbf{9}$ & Behavior & 125 & 565 & 3 \\
$\mathbf{1 0}$ & Biodiversity & 107 & 547 & 1 \\
\hline \multicolumn{5}{c}{ Table 7: Keywords in wildlife tourism } \\
\multicolumn{5}{c}{ Source: Authors }
\end{tabular}

The most frequent keywords were "conservation" (occurrence 350 and link strength 1,547), "tourism" $(3,971,472)$, "wildlife" $(2,821,256)$, "management" $(2,441,171)$, “ecotourism" (211,964), "protected areas" (149,767), "wildlife tourism" (184,710), "attitudes" (111,589), "behavior" $(125,565)$, and "biodiversity" $(107,547)$.

Overall analysis indicates that the keywords could be classified into four categories, namely: (i) conservation, (ii) behavior, (iii) wildlife, and (iv) ecosystems-climate. The keyword related to science, i.e. "conservation" takes the front seat as compared to tourism-related keywords. When the keywords are categorized based on pure sciences and tourism, a majority of the keywords fall in the domain of science. However, all the keywords mentioned earlier are very relevant to WT literature, addressing wildlife management at destinations. The keywords such as tourism, management, eco-tourism, and attitudes of tourists belong to pure tourism studies. Hence, it is evident from the earlier-mentioned results that studies based on pure sciences on the impacts on wildlife and the environment are inseparable from WT literature. These clear-cut clusters can be adopted by the researchers for further studies and classification purposes.

Figure 6 suggests that the yellow cluster (which encompasses the following keywords: ecosystem, climate change, vegetation, and habitat), needs specific attention from the researchers in the field of WT. This also helps in understanding that cluster four seems weak and offers more potential to the young researchers. This could also be used as guidelines and to make future research more promising. 


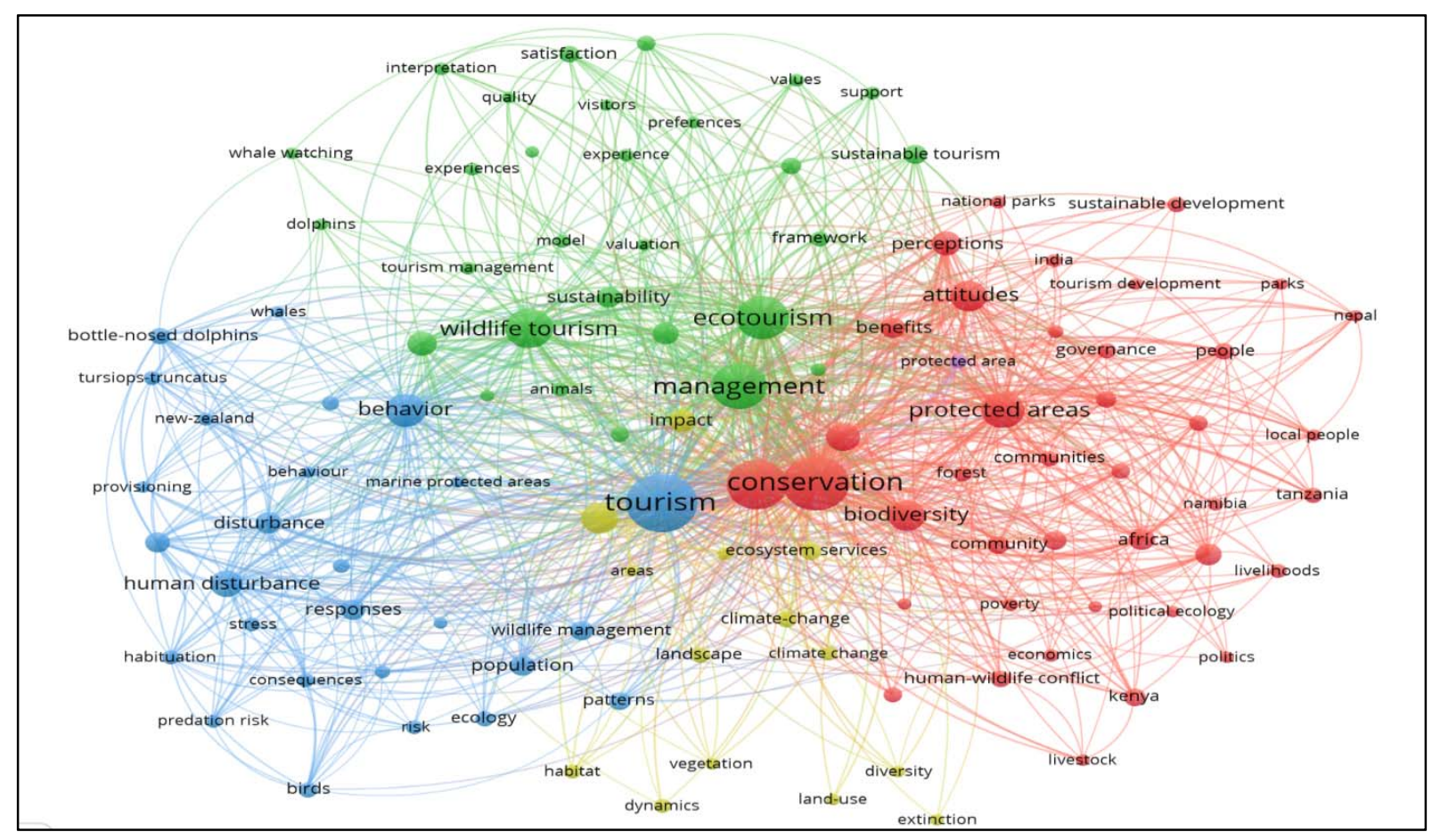

Figure 6: Structural relationship among keywords in wildlife tourism Source: Authors

\section{6) COUNTRIES WITH HIGH CITATIONS}

This study analyzed the structure of research collaboration between countries in the area of WT, intending to understand the behaviors of research teams. The distance between the nodes represents the degree of collaboration between the countries in the research area of WT, and their influence is represented in diverse nodes. Out of 113 countries that published WT research, 57 have a minimum of 5 documents and 10 citations. According to link strength and number of documents and citations, the 113 countries are grouped into nine clusters (see Table 8). The ranking method used for Table 8 was ordinal ranking.

\begin{tabular}{clccc} 
Rank & Countries & Documents & Citations & Clusters \\
\hline $\mathbf{1}$ & USA & 388 & 8,783 & 1 \\
$\mathbf{2}$ & Australia & 263 & 5,775 & 3 \\
$\mathbf{3}$ & England & 149 & 3,741 & 4 \\
$\mathbf{4}$ & Canada & 126 & 2,992 & 3 \\
\hline \multicolumn{5}{c}{413}
\end{tabular}




\begin{tabular}{clccc}
\hline $\mathbf{5}$ & South Africa & 125 & 1,480 & 1 \\
$\mathbf{6}$ & Scotland & 45 & 1,354 & 6 \\
$\mathbf{7}$ & New Zealand & 47 & 1,249 & 3 \\
$\mathbf{8}$ & Kenya & 57 & 1,154 & 1 \\
$\mathbf{9}$ & Switzerland & 34 & 1,115 & 2 \\
$\mathbf{1 0}$ & Germany & 53 & 1,032 & 2 \\
\hline \multicolumn{5}{c}{ Table 8: Countries with high citations in wildlife tourism } \\
\multicolumn{4}{c}{ Source: Authors }
\end{tabular}

According to the number of documents and citations of the countries, the US (documents 388 and citations 8,783) has led cluster one: New Zealand $(471,249)$, Kenya $(571,154)$, and Switzerland $(341,115)$ have led; cluster two: Australia $(2,635,775)$ has led; cluster three: England $(1,493,741)$ has led; cluster four: Canada $(1,262,992)$, South Africa $(1,251,480)$, and Scotland $(451,354)$ have led; and cluster six: Germany $(531,032)$, Spain $(43,994)$, Norway $(44,966)$, and India $(46,573)$ have this cluster.

It can be observed from the relationship structure among the countries that the US, South Africa, and Kenya of cluster one have strong collaborations in WT publications. Similarly, Switzerland, Germany, and Spain belong to cluster two; Australia, Canada, and New Zealand belong to cluster three; England, India, Norway, and Portugal belong to cluster four. According to the link strength and citations, the first cluster is led by the US (cluster in red color), followed by South Africa. It is observed from Table 8 that African countries have more dominance in cluster one. Cluster two belongs to European countries and cluster three is dominated by Australia. Hence, it can be understood that a majority of the research studies in wildlife areas have been taken up in the US, Africa, Europe, and Australia. It is a well-known fact that wildlife resources are predominant in Africa, followed by Australia. Hence, it is evident from this analysis that a majority of the research studies, too, are present in these continents.

\section{DISCUSSION AND FUTURE RESEARCH}

The paper aims to give a broader view of the trends and structure of the literature in WT from the past two decades. The study stresses the importance of WT to the economy and the researchers. The study discusses the issues theoretically and also highlights the 
relevance of research in WT in the present scenario. Hence, the study has explored the topic of WT; its multi-dimensional areas that encompass conservation, community role and its impact, sustainability, tourism management, tourist behavior, protected areas, wildlife animals, marine, and ecology.

Initially, the literature study searched for the earlier bibliometric analysis studies and structures in the field of WT. However, no bibliometric and visualization analyses were found in the area of WT literature. Considering the prevailing scenario and the significance of the bibliometric approach, this study investigated the bibliometric and visualization analyses of WT-related articles. The findings of the analysis emphasized the need to consider the area of WT from an interdisciplinary perspective. WT is an integration of various disciplines of science like ecology, conservation, sustainability, marine life, and protected areas. On the other hand, tourism management, WT, community impact and its role, tourist behavior, and economics with a management perspective are integral parts of WT.

The research in the area of WT had been evolving consistently from 2000 and has experienced massive growth from 2016 to 2020 . 1,259 documents have been published in the area of WT in the last two decades. The articles considered in the study are those published in reputed journals with indexing in SCOPUS and WOS databases since they have reliable coverage. A total of 4,064 authors and 113 countries are working in the area of WT with more than 25,000 citations. Currently, more than 200 articles are being published each year in WT. Though we could see growth in the publications in WT, literature pertaining to it is still scarce. This paper is pioneering in analyzing the trends and structure of WT research.

Examining databases like SCOPUS and WOS gave an indication that the top five journals publishing research on WT are Tourism Management, Biological Conservation, Journal of Sustainable Tourism, Environmental Conservation, and Conservation Biology. Further, the main categories of publication are conservation, tourism management, biology, sustainability, and wild animals. These categories are expanding to other disciplines.

The keyword occurrence analysis reveals that "conservation," "tourism," "wildlife," "management," and "ecotourism" are the prominently used keywords in the literature of 
WT. This indicates the relevance of tourism, management, behavioral studies, and environmental science as broad discipline areas found in the literature. The cooccurrence analysis indicates the prominent countries focusing on the area of WT to be South Africa, New Zealand, Kenya, Nepal, Namibia, and Tanzania (Figure 6).

Co-citation analysis indicated the top-cited articles written by Woodall and Lucy, C., followed by Buckley, among 1,259 documents of WT literature. The author co-citation analysis revealed six clusters, of which authors from the first two clusters are top-cited; Ballantyne Roy and Packer Jan are the authors who led the rank out of 4,064 authors who published research on WT. Interestingly, these two authors are colleagues working at the University of Queensland. Ballantyne Roy deals with visitor research, environmental learning and interpretation, eco-wildlife tourism, and environmental education, while Packer Jan deals with visitors' experience, zoos, aquariums, and sustainability. Cluster two is led by Bejder Lars and Gallagher Austin J., who belong to Dalhousie University and the University of Miami, respectively. Bejder Lars' research interests are in the areas of conservation biology, animal behavior, impact assessment, social structure, and resource management. At the same time, Gallagher Austin J.'s research interests are in the areas of behavior, physiology, ecology, marine biology, and conservation biology.

The bibliographic coupling of authors indicated twelve clusters and the top-ten authors belong to clusters three, four, and five. Dearden Philip, who leads cluster three, focused his studies on conservation, protected areas, and marine tropics, followed by Huveneers Charlie. His studies were in the area of fish biology and ecology. Newsome David, who leads cluster four, dealt with ecotourism, WT, geo-tourism, and protected area management. Lusseau David, who leads cluster five, deals with quantitative behavior, quantitative biology, quantitative governance, sustainability, and decision theory.

The citation analysis of WT literature indicated the predominant WT studies are carried out in countries like the US, Africa, and Australia. The study indicates that the top institutes analyzing the tourism field (by author affiliation analysis) are the Queensland University, Griffith University, Dalhousie University, Murdoch University, the University of Miami, Centre for Wildlife Studies, the University of Oxford, and the University of Ben. 


\section{CONCLUSIONS AND LIMITATIONS}

RQ1: What is the current state of the knowledge base/structure of WT? This study on bibliometric analysis of WT literature has indicated diverse and broad areas of research that should be integrated and reconciled in the diverse perspectives. The broad areas of study identified are conservation, ecology, sustainability, wildlife animals, protected areas and environmental impacts, aspects of science, tourism, management, economics, local community, and visitors' behavior. These results are essential to practitioners for drawing the required policies. It is also significant for researchers to understand the connections between the sub-topics of WT and some new topics that could open new areas for research. The key is "collaboration as a way of sharing knowledge and improving research performance." A large network of collaborations is missing, in totality.

RQ2: Which research front/conceptual structure of WT is most popular and where are the academics lacking? The policymakers need to integrate and have balance in addressing the issues of diverse fields of WT like environmental issues, ecology, conservation, and sustainability on one side; and on the other side, focusing on visitors' satisfaction, management, economics, and local community for developing a sustainable and a popular destination of WT. It is observed that there are inadequate studies on crowd management, risk and safety, social media, and technological aspects in WT. However, the earlier-mentioned areas are also crucial to consider while designing policies for the sustainable development of WT.

The researchers can get the advantage of this study by venturing into new areas and focusing on areas where there are inadequate studies. This study gives researchers a comprehensive understanding of the literature piled up during the last two decades through structure and relationship analysis.

RQ3: What is the shape of the social network structure of the WT researchers' community? The study gives an overall idea about prominent researchers in this field, trends in WT, which countries are collaborating in WT research, and what are journals that are publishing research on this topic. This study also stresses the need to attract attention to the areas within management like marketing, human resource management, 
innovation, and ethics. This suggests that academicians from social sciences are not actively researching WT.

Bottleneck of this research is that the studies on WT need to focus more on empirical and methodological articles related to the diverse areas in WT, which seems to be missing.

\section{1) LIMITATIONS}

Apart from this conclusion, the study has its limitations that can also help authors with their future research. The methodology of using bibliometric and visualization analysis is an objective treatment of keywords, author(s') names, journals, and references of an article that could exacerbate perplexing results if the study is not supplemented with qualitative studies. Secondly, the sample of the study was collected from WOS and SCOPUS indexed journals, not considering other indexing sources. To add to it, the study has considered articles published in journals, not considering the proceedings, books, letters, and notes. Hence, avoiding these limitations in future studies can offer new and exciting analyses.

Prospective studies in the future can focus on the trends visualized through different analyses used in the present study. The researchers could observe the evolution of keywords in the area of WT literature and make an in-depth analysis of various clusters or themes mentioned in the study. Furthermore, the researchers can adopt new methodologies in bibliometric analysis to study and structure WT literature. Further, researchers can use other software such as BibExcel, CiteSpace, Eigenfactor Score, HistCite, and Pajek for deeper analysis of literature. All these could enrich and extend the literature of WT.

\section{Acknowledgments}

The authors would like to thank the anonymous reviewer for their tremendous efforts for getting us successful. 


\section{References}

Acedo, F.J.; Barroso, C.; Galan, J.L. The resource-based theory: Dissemination and main trends. Strategic Management Journal, Vol. 27, No 7, 2006, pp. 621-636.

Álvarez-García, J.; Durán-Sánchez, A.; Río-Rama, D.; De la Cruz, M. Scientific coverage in community-based tourism: Sustainable tourism and strategy for social development. Sustainability. Vol. 10, No 4, 2018, pp. 1158.

Álvarez-García, J.; Maldonado-Erazo, C. P.; Sánchez-Fernández, M.D. Creative tourism in small cities and rural areas: A bibliographic review. Enlightening Tourism. A Pathmaking Journal, Vol. 9, No 1, 2019, pp. 63-94.

Auster, R.E.; Barr, S.W.; Brazier, R.E. Wildlife tourism in reintroduction projects: Exploring social and economic benefits of beaver in local settings. Journal for Nature Conservation, Vol. 58, No 1, 2020, pp. 125920.

Ballantyne, R.; Packer, J.; Falk, J. Visitors' learning for environmental sustainability: Testing short-and long-term impacts of wildlife tourism experiences using structural equation modelling. Tourism Management, Vol. 32, No 6, 2011, pp. 1243-1252.

Ballantyne, R.; Packer, J.; Sutherland, L.A. Visitors' memories of wildlife tourism: Implications for the design of powerful interpretive experiences. Tourism Management, Vol. 32, No 4, 2011, pp. 770-779.

Barrios, M.; Borrego, A.; Vilaginés, A., Ollé, C.; Somoza, M. A bibliometric study of psychological research on tourism. Scientometrics, Vol. 77, No 3, 2008, pp. 453-467.

Bejder, L.; Samuels, A.; Whitehead, H.; Gales, N.; Mann, J.; Connor, R.; Heithaus, M.; Watson-Capps, J.; Flaherty, C.; Krützen, M. Decline in relative abundance of bottlenose dolphins exposed to long-term disturbance. Conservation Biology, Vol. 20, No 6, 2006, pp. 1791-1798. 
Belhassen, Y.; Caton, K. Advancing understandings: A linguistic approach to tourism epistemology. Annals of Tourism Research, Vol. 36, No 2, 2009, pp. 335-352.

Benckendorff, P.; Zehrer, A. A network analysis of tourism research. Annals of Tourism Research, Vol. 43, No 1, 2013, pp. 121-149.

Bilynets, I.; Cvelbar, L.K. Past, present and future of the research on the proenvironmental behaviour in tourism: A bibliometric analysis. Economic and Business Review for Central and South-Eastern Europe, Vol. 22, No 2, 2020, pp. 289-312.

Blanco-Mesa, F.; Merigó, J. M.; Gil-Lafuente, A. M. Fuzzy decision making: A bibliometricbased review. Journal of Intelligent \& Fuzzy Systems, Vol. 32, No 3, 2017, pp. 2033-2050.

Boyle, F.; Sherman, D. Scopus ${ }^{\mathrm{TM}}$ : The product and its development. The Serials Librarian, Vol. 49, No. 3, 2006, pp. 147-153.

Broadus, R.N. Toward a definition of "bibliometrics". Scientometrics, Vol. 12, No 5-6, 1987, pp. 373-379.

Buckley, R. Sustainable tourism: Research and reality. Annals of Tourism Research, Vol 39, No 2, 2012, pp. 528-546.

Buckley, R.; Brough, P.; Hague, L.; Chauvenet, A.; Fleming, C.; Roche, E.; Sofija, E.; Harris, N. Economic value of protected areas via visitor mental health. Nature Communications, Vol. 10, No 1, 2019, pp. 1-10.

Callon, M.; Courtial, J.-P.; Turner, W. A.; Bauin, S. From translations to problematic networks: An introduction to co-word analysis. Information (International Social Science Council), Vol. 22, No. 2, 1983, pp. 191-235.

Cardoso, L.; Silva, R.; Almeida, G.G.F.D.; Lima Santos, L. A bibliometric nodel to analyze country research performance: SciVal topic prominence approach in tourism, leisure and hospitality. Sustainability, Vol. 12, No 23, 2020, pp. 9897. 
Chang, C.L.; McAleer, M. Citations and impact of ISI tourism and hospitality journals. Tourism Management Perspectives, Vol. 1, No 1, 2012, pp. 2-8.

Cobo, M.J.; López-Herrera, A.G.; Herrera-Viedma, E.; Herrera, F. Science mapping software tools: Review, analysis, and cooperative study among tools. Journal of the American Society for Information Science and Technology, Vol. 62, No 7, 2011, pp. 13821402.

Cong, L.; Newsome, D.; Wu, B.; Morrison, A. M. Wildlife tourism in China: A review of the Chinese research literature. Current Issues in Tourism, Vol. 20, No 11, 2017, pp. 11161139.

Coppes, J.; Nopp-Mayr, U.; Grünschachner-Berger, V.; Storch, I.; Suchant, R.; Braunisch, V. Habitat suitability modulates the response of wildlife to human recreation. Biological Conservation, Vol. 227, No 1, 2018, pp. 56-64.

Dou, X.; Day, J. Human-wildlife interactions for tourism: A systematic review. Journal of Hospitality and Tourism Insights. Vol. 3, No 5, 2020, pp. 529-547.

Falagas, M.E.; Pitsouni, E.I.; Malietzis, G.A.; Pappas, G. Comparison of PubMed, Scopus, Web of Science, and Google Scholar: Strengths and weaknesses. The FASEB Journal, Vol. 22, No. 2, 2008, pp. 338-342.

Gallagher, A.J.; Huveneers, C.P. Emerging challenges to shark-diving tourism. Marine Policy, Vol. 96, No 1, 2018, pp. 9-12.

Garrigos-Simon, F.J.; Narangajavana-Kaosiri, Y.; Lengua-Lengua, I. Tourism and sustainability: A bibliometric and visualization analysis. Sustainability, Vol. 10, No 6, 2018, pp. 1-23.

Hall, C.M. Publish and perish? Bibliometric analysis, journal ranking and the assessment of research quality in tourism. Tourism Management, Vol. 32, No 1, 2011, pp. 16-27. 
Hofman, K., Hughes, K., Walters, G. Effective conservation behaviours for protecting marine environments: The views of the experts. Journal of Sustainable Tourism, Vol. 28, No 10,2020 , pp. 1-19.

Jamal, T.; Smith, B.; Watson, E. Ranking, rating and scoring of tourism journals: Interdisciplinary challenges and innovations. Tourism Management, Vol. 29, No 1, 2008, pp. 66-78.

Jarneving, B. A comparison of two bibliometric methods for mapping of the research front. Scientometrics, Vol. 65, No 2, 2005, pp. 245-263.

Karanth, K.K.; Gopalaswamy, A.M.; Prasad, P.K.; Dasgupta, S. Patterns of humanwildlife conflicts and compensation: Insights from Western Ghats protected areas. Biological Conservation, Vol. 166, No. 1, 2013, pp. 175-185.

Kaurav, R.P.S.; Baber, R.; Rajput, S. Technology-driven tourism and hospitality industry as a tool for economic development: A bibliometric analysis. In Hassan, A.; Sharma, A. (Eds.). The Emerald Handbook of ICT in Tourism and Hospitality. Bingley: Emerald Publishing Limited, 2020, pp. 469-486.

Khanra, S.; Dhir, A.; Kaur, P.; Mäntymäki, M. Bibliometric analysis and literature review of ecotourism: Toward sustainable development. Tourism Management Perspectives, Vol. 37, No 1, 2021 , pp. 100777.

Knight, J. The ready-to-view wild monkey: The convenience principle in Japanese wildlife tourism. Annals of Tourism Research, Vol. 37, No 3, 2010, pp. 744-762.

Koseoglu, M.A.; Rahimi, R.; Okumus, F.; Liu, J. Bibliometric studies in tourism. Annals of Tourism Research, Vol. 61, No 1, 2016, pp. 180-198.

Krüger, O. The role of ecotourism in conservation: Panacea or Pandora's box? Biodiversity Conservation, Vol. 14, No 3, 2005, pp. 579-600. 
Leydesdorff, L.; Vaughan, L. Co-occurrence matrices and their applications in information science: Extending ACA to the Web environment. Journal of the American Society for information Science and Technology, Vol. 57, No 12, 2006, pp. 1616-1628.

Lima Santos, L.; Cardoso, L.; Araújo-Vila, N.; Fraiz-Brea, J.A. Sustainability perceptions in tourism and hospitality: A mixed-method bibliometric approach. Sustainability, Vol. 12, No 21, 2020, pp. 8852.

Liu, S.; Li, W.Y. Ecotourism research progress: A bibliometric analysis during 1990-2016. SAGE Open, Vol. 10, No 2, 2020, pp. 1-12.

Liwen, T.; Jingkun, D. The frontier and evolution of the strategic management theory in 21th century: A scientometric analysis of strategic management journal, from 2001 to 2012. Nankai Business Review, Vol. 17, No 2, 2014, pp. 84-94.

Lu, K.; Wolfram, D. Measuring author research relatedness: A comparison of word-based, topic-based, and author cocitation approaches. Journal of the American Society for information Science and Technology, Vol. 63, No 10, 2012, pp. 1973-1986.

McCain, K.W. Mapping authors in intellectual space: A technical overview. Journal of the American Society for Information Science (1986-1998), Vol. 41, No. 6, 1990, pp. 433-443.

McKercher, B. A citation analysis of tourism scholars. Tourism Management, Vol. 29, No. 6, 2008, pp. 1226-1232.

Merigó, J.M.; Mulet-Forteza, C.; Martorell, O.; Merigó-Lindahl, C. Scientific research in the tourism, leisure and hospitality field: A bibliometric analysis. Anatolia, Vol. 31, No 3, 2020, pp. 494-508.

Moorhouse, T.P.; Dahlsjö, C.A.; Baker, S.E.; D'Cruze, N.C.; Macdonald, D.W. The customer isn't always right-conservation and animal welfare implications of the increasing demand for wildlife tourism. PloS one, Vol. 10, No 10, 2015, pp. e0138939. 
Mulet-Forteza, C.; Martorell-Cunill, O.; Merigó, J.M.; Genovart-Balaguer, J.; MauleonMendez, E. Twenty five years of the Journal of Travel \& Tourism Marketing: A bibliometric ranking. Journal of Travel \& Tourism Marketing, Vol. 35, No. 9, 2018, pp. 1201-1221.

Müllner, A.; Linsenmair, K.E.; Wikelski, M. Exposure to ecotourism reduces survival and affects stress response in hoatzin chicks (Opisthocomus hoazin). Biological Conservation, Vol. 118, No 4, 2004, pp. 549-558.

Nerur, S.; Rasheed, A.A.; Pandey, A. Citation footprints on the sands of time: An analysis of idea migrations in strategic management. Strategic Management Journal, Vol. 6, No 37, 2016, pp. 1065-1084.

Nerur, S.P.; Rasheed, A.A.; Natarajan, V. The intellectual structure of the strategic management field: An author co-citation analysis. Strategic Management Journal, Vol. 29, No 3, 2008, pp. 319-336.

Newsome, D.; Moore, S.A.; Dowling, R.K. Natural Area Tourism: Ecology, Impacts and Management. Clevedon, UK: Channel View Publications, 2012.

Orams, M.B. Feeding wildlife as a tourism attraction: A review of issues and impacts. Tourism Management, Vol. 23, No 3, 2002, pp. 281-293.

Packer, J.; Ballantyne, R.; Luebke, J.F. Exploring the factors that influence zoo visitors' perceptions of the well-being of gorillas: Implications for zoo exhibit interpretation. Visitor Studies, Vol. 21, No 1, 2018, pp. 57-78.

Park, K.; Phillips, W.J.; Canter, D.D.; Abbott, J. Hospitality and tourism research rankings by author, university, and country using six major journals: The first decade of the new millennium. Journal of Hospitality \& Tourism Research, Vol. 35, No 3, 2011, pp. 381-416.

Perianes-Rodríguez, A.; Waltman, L.; Van Eck, N.J. Constructing bibliometric networks: A comparison between full and fractional counting. Journal of Informetrics, Vol. 10, No 4, 2016, pp. 1178-1195. 
Pilkington, A.; Lawton, T.C. Divided by a common language? Transnational insights into epistemological and methodological approaches to strategic management research in English-speaking countries. Long Range Planning, Vol. 47, No. 5, 2014, pp. 299-311.

Pinkus, E.; Moore, S.A.; Taplin, R.; Pearce, J. Re-thinking visitor loyalty at 'once in a lifetime' nature-based tourism destinations: Empirical evidence from Purnululu National Park, Australia. Journal of Outdoor Recreation and Tourism, Vol. 16, No 1, 2016, pp. 715.

Reynolds, P.C.; Braithwaite, D. Towards a conceptual framework for wildlife tourism. Tourism Management, Vol. 22, No 1, 2001, pp. 31-42.

Rodger, K.; Moore, S.A.; Newsome, D. Wildlife tours in Australia: Characteristics, the place of science and sustainable futures. Journal of Sustainable Tourism, Vol. 15, No 2, 2007, pp. 160-179.

Ronda-Pupo, G.A.; Guerras-Martin, L.A. Dynamics of the evolution of the strategy concept 1962-2008: A co-word analysis. Strategic Management Journal, Vol. 33, No 2, 2012, pp. 162-188.

Schmidgall, R.; Woods, R.H.; Hardigree, C. Hospitality's most influential scholars: Fifteen years of citation analyses (1989-2004). Journal of Hospitality \& Tourism Education, Vol. 19, No 2, 2007, pp. 32-43.

Sedarati, P.; Santos, S.; Pintassilgo, P. System dynamics in tourism planning and development. Tourism Planning \& Development, Vol. 16, No 3, 2019, pp. 256-280.

Semeniuk, C.A.; Haider, W.; Cooper, A.; Rothley, K.D. A linked model of animal ecology and human behavior for the management of wildlife tourism. Ecological Modelling, Vol. 221, No 22, 2010, pp. 2699-2713.

Small, H. Co-citation in the scientific literature: A new measure of the relationship between two documents. Journal of the American Society for Information Science, Vol. 24, No 4, 1973, pp. 265-269. 
Tokić, K.; Tokić, I. Bibliometric analysis from the perspective of a Croatian Tourism Journal. Qualitative and Quantitative Methods in Libraries, Vol. 4, No 4, 2017, pp. 927 936.

Triantafyllou, G.; Toanoglou, M.; Eirini, S.; Kaurav, R.P.S. How Web of Science is shaping the researches on publications on wine tourism: Bibliometric analysis approach. Journal of Tourism Quarterly, Vol. 2, No 3-4, 2020, pp. 67-78.

Üsdiken, B.; Pasadeos, Y. Organizational analysis in North America and Europe: A comparison of co-citation networks. Organization Studies, Vol. 16, No. 3, 1995, pp. 503526.

Van Eck, N.J.; Waltman, L. Software survey: VOS viewer, a computer program for bibliometric mapping. Scientometrics, Vol. 84, No 2, 2010, pp. 523-538.

Vaske, J.J.; Shelby, L.B.; Manfredo, M.J. Bibliometric reflections on the first decade of human dimensions of wildlife. Human Dimensions of Wildlife, Vol. 11, No 2, 2006, pp. 7987.

Weaver, D.B.; Lawton, L.J. Twenty years on: The state of contemporary ecotourism research. Tourism Management, Vol. 28, No 5, 2007, pp. 1168-1179.

White, H.D.; Griffith, B.C. Author co-citation: A literature measures of intellectual structure. Journal of the American Society for Information Science, Vol. 32, No 3, 1981, pp. 163-171.

White, H.D.; McCain, K.W. Visualizing a discipline: An author co-citation analysis of information science, 1972-1995. Journal of the American Society for Information Science, Vol. 49, No 4, 1998, pp. 327-355.

Winter, C. A review of animal ethics in tourism: Launching the annals of tourism research curated collection on animal ethics in tourism. Annals of Tourism Research, Vol. 84, No 1, 2020, pp. 102989. 
Woodall, L.C.; Sanchez-Vidal, A.; Canals, M.; Paterson, G.L.; Coppock, R.; Sleight, V.; Calafat, A.; Rogers, A.D.; Narayanaswamy, B.E.; Thompson, R.C. The deep sea is a major sink for microplastic debris. Royal Society Open Science, Vol. 1, No 4, 2014, pp. 140317.

WTTC. The Economic Impact of Global Wildlife Tourism Report. World Tourism \& Travel Council, 2019. Retrieve from https://travesiasdigital.com/wpcontent/uploads/2019/08/The-Economic-Impact-of-Global-Wildlife-Tourism-Final-19.pdf (accessed 1 July 2021).

Xiao, H.; Smith, S.L. The maturation of tourism research: Evidence from a content analysis. Tourism Analysis, Vol. 10, No 4, 2006, pp. 335-348.

Zhang, S.; Chan, E.S. A modernism-based interpretation of sustainable tourism. International Journal of Tourism Research, Vol. 22, No 2, 2020, pp. 223-237.

Zhang, S.J.; Lyu, P.H.; Yan, Y. Global geographical and scientometric analysis of tourismthemed research. Scientometrics, Vol. 105, No 1, 2015, pp. 385-401.

Zhao, W.; Ritchie, J.B. An investigation of academic leadership in tourism research: 19852004. Tourism Management, Vol. 28, No 2, 2007, pp. 476-490.

Zopiatis, A.; Theocharous, A.L.; Constanti, P. The past is prologue to the future: An introspective view of hospitality and tourism research. Scientometrics, Vol. 102, No 2, 2015, pp. 1731-1753.

Zupic, I.; Čater, T. Bibliometric methods in management and organization. Organizational Research Methods, Vol. 18, No 3, 2015, pp. 429-472.

Article info: Received 21/12/2020. Accepted 13/07/2021. Refereed anonymously. 